\title{
Effect of hyperthyroidism on bronchial reactivity in non-asthmatic patients
}

\author{
J A ROBERTS, A R MCLELLAN, W D ALEXANDER, N C THOMSON \\ From the Department of Respiratory Medicine, Western Infirmary, Glasgow, and the Department of Medicine, \\ University of Glasgow
}

ABSTRACT Thyrotoxicosis may be associated with deterioration in asthma. To determine whether bronchial reactivity to histamine is increased in hyperthyroidism 10 thyrotoxic non-asthmatic patients were assessed before and after treatment of their thyrotoxicosis. No significant change in bronchial reactivity was found after treatment.

Changes in thyroid function are associated with changes in the severity of symptoms in patients with asthma, ${ }^{1-4}$ thyrotoxicosis being associated with deterioration in asthma control. ${ }^{124}$ As bronchial hyperreactivity is an important feature of asthma, we have examined whether the effect of altered thyroid hormone state on asthmatic symptoms can be explained by changes in airway responsiveness to histamine.

\section{Methods}

Ten subjects (nine female; age range $30-68$, mean $45 \cdot 4$ years) with thyrotoxicosis were studied before and after antithyroid treatment. No patients were taking beta adrenergic blockers. Thyroid stimulating hormone (TSH) receptor antibody concentrations (TRab) were measured by the method of Shering and Peer-Smith. Thyroxine and triiodothyronine were estimated with Amerlex RIA kits (Amersham, UK) and TSH by IRMA with the Sucresep kit (Boots, Celltech, UK).

All subjects had Graves disease associated with raised concentrations of TSH receptor antibodies (mean $(95 \%$ confidence intervals) $38 \cdot 3(30 \cdot 2-46 \cdot 4)$ ), expressed as percentage inhibition of TSH binding (normal range $-8 \%$ to $+8 \%$ ). All were biochemically thyrotoxic (and untreated) at initial assessment (thyroxine 226.9 (208.9-224.9) $\mathrm{nmol} / \mathrm{l}$; normal range 54-142 nmol/1), triiodothyronine 5.4 (4.5-6.3) $\mathrm{nmol} / \mathrm{l}$; normal range $0 \cdot 8-2 \cdot 7 \mathrm{nmol} / \mathrm{l})$, TSH undetectable (normal range $0 \cdot 8-5 \cdot 45 \mathrm{mU} / \mathrm{l})$ ). Patients were rendered euthyroid with thioureylene antithyroid drugs (nine with carbimazole, one with propylthiouracil) and were restudied after a sustained period of euthyroidism (6-14 months after initial treatment). Post-treatment thyroxine was $116 \cdot 3$ (SD $12 \cdot 2) \mathrm{nmol} / \mathrm{l}$, triiodothyronine $1 \cdot 6(0 \cdot 2) \mathrm{nmol} / \mathrm{l}$, TSH $2 \cdot 3(0 \cdot 7)$ $\mathrm{mU} / \mathrm{l})$. Seven subjects reported breathlessness associated with exercise but none had a history of respiratory disease. Five were cigarette smokers and remained so during the

Address for correspondence: Dr J A Roberts, Medicine 1 (D level, Centre Block), Southampton General Hospital, Southampton SO9 4XY. (Reprints will not be available.)

Accepted 22 March 1989 study. Four subjects were atopic as defined by a $>2 \mathrm{~mm}$ prick skin weal response to one or more of seven common antigenic substances (house dust, Dermatophagoides pteronyssinus, cat fur, dog dander, mixed feathers, mixed grass

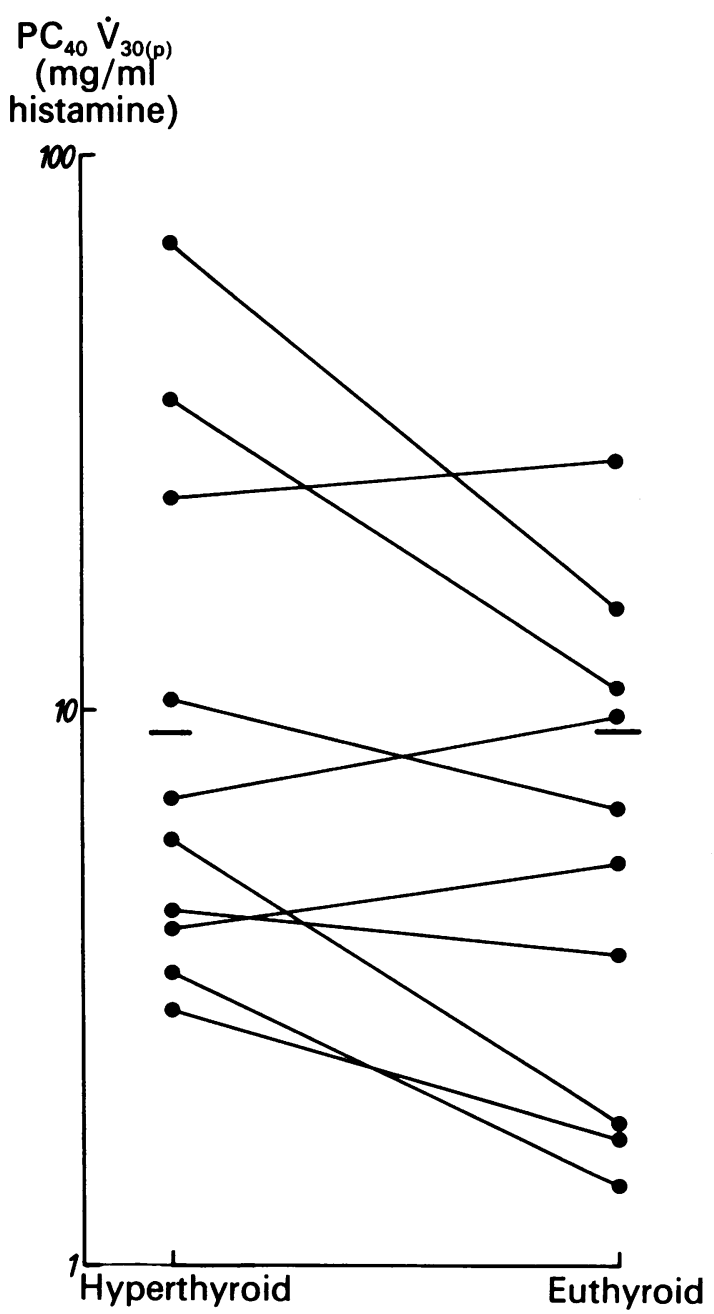

Provocative concentration of histamine causing a $40 \%$ fall in partial expiratory flow rate at $30 \%$ of vital capacity $\left(P C_{40} \dot{V}_{30(p)}\right)$ before and after treatment for each patient (geometric mean values shown as a horizontal bar). 
pollen and Aspergillus fumigatus) but none had allergic rhinitis. Pulmonary function tests were performed and bronchial reactivity to histamine (doubling dilutions via a Wright's nebuliser, output $0 \cdot 15 \mathrm{ml} / \mathrm{min}$ ) was measured at the same time of day before and after correction of the hyperthyroidism. FEV and the partial expiratory flow rate at $30 \%$ of vital capacity $\left(\dot{\mathrm{V}}_{30(\mathrm{p})}\right)$ were measured automatically (Collingwood Measurement). From the concentration-response curve the provocation concentrations causing a $10 \%$ fall in FEV $_{1}\left(\mathrm{PC}_{10} \mathrm{FEV}_{1}\right)$ and a $40 \%$ fall in $\dot{\mathrm{V}}_{30(\mathrm{p})}\left(\mathrm{PC}_{40} \dot{\mathrm{V}}_{30 \mathrm{p})}\right)$ were calculated. Baseline airway calibre and $\log \mathrm{PC}_{10} \mathrm{FEV}_{1}$ and $\mathrm{PC}_{40} \dot{\mathrm{V}}_{30(\mathrm{p})}$ were compared by means of Student's paired $t$ test. Multiple regression analysis was used to compare measures of respiratory function and thyroid hormone activity.

\section{Results}

Baseline $\mathrm{FEV}$, ranged from $97 \%$ to $137 \%$ predicted and did not change significantly after treatment. The pretreatment thyroxine concentration correlated inversely with baseline $\mathrm{FEV}_{1}(\mathrm{r}=-0.74, \mathrm{p}<0.05)$. Geometric mean $(95 \%$ confidence interval) $\mathrm{PC}_{10} \mathrm{FEV}_{1}$ and $\mathrm{PC}_{40} \dot{\mathrm{V}}_{30(\mathrm{p})}$ values before treatment were $10.6(5 \cdot 3-20.8) \mathrm{mg} / \mathrm{ml}$ and $9 \cdot 2(4.9-17 \cdot 1) \mathrm{mg} /$ $\mathrm{ml}$; after treatment they were $9 \cdot 1(4 \cdot 8-17 \cdot 9)$ and $5 \cdot 5(3 \cdot 0-10 \cdot 4)$ $\mathrm{mg} / \mathrm{ml}$ (figure).

\section{Discussion}

The deleterious effect of hyperthyroidism on asthma has been recognised for many years ${ }^{124}$ and correction of hypothyroidism with thyroxine may exacerbate pre-existing asthma. ${ }^{3}$ Cockcroft $e t$ al $^{5}$ reported a decrease in nonspecific bronchial reactivity in an asthmatic patient after treatment of hyperthyroidism. A prospective study of administration of triiodothyronine to normal subjects, however, did not increase airway reactivity. ${ }^{6}$ This study used a three week treatment period, which might not have been long enough to induce thyrotoxic changes in the airway. The mechanism by which thyroid hormone worsens symptoms of asthma is not clear, though one study found an increase in beta adrenergic responsiveness in non-asthmatic patients after treatment of hyperthyroidism. ${ }^{7}$ We were unable to find any change in bronchial reactivity in a group of non- asthmatic patients after correction of hyperthyroidism. In $\stackrel{\sim}{\times}$ agreement with this finding, Kendrick et al reported a lack of change in bronchial reactivity to methacholine in a similar group of patients. ${ }^{8}$

Although weakness of respiratory muscles has previously been found in thyrotoxicosis," this mechanism alone is unlikely to account for the changes in symptoms of asthma. Respiratory muscle weakness could, however, contribute to the dyspnoea that commonly accompanies thyrotoxicosis, ${ }^{8}$ and it may heighten the degree of breathlessness experienced by a patient with pre-existing airways disease.

Thus, although thyroxine did relate to baseline calibre, bronchial reactivity was not increased in our thyrotoxic subjects and did not change when the euthyroid state was achieved. Our results do not suggest that increased bronchial reactivity explains deterioration in asthma control in thyrotoxicosis, though an alteration in bronchial responsiveness specifically in asthmatic patients cannot be excluded by the results of our study.

\section{References}

1 Elliot CA. Occurrence of asthma in patients manifesting evidence of thyroid dysfunction. Am J Surg 1929;7:333-7.

2 Ayres J, Clark TJH. Asthma and the thyroid. Lancet 1981;ii:1110.

3 Fedrick J, Badwin JA. Thyroid disease and asthma. $\mathrm{Br}$ Med J 1977;ii:1539.

4 Fitzpatrick WSF, Foreman PS, Porter EJB, Beckett AG. Hyperthyroidism and acute bronchial asthma. $\mathrm{Br} \mathrm{Med} J$ 1984;288: 314-5.

5 Cockcroft DW, Silverberg JDH, Dosman JA. Decrease in nonspecific bronchial reactivity in an asthmatic patient following treatment of hyperthyroidism. Ann Allergy 1978;41:160-3.

6 Irwin RS, Pratter MR, Stivers DH, Braverman LE. Airway reactivity and lung function in triiodothyronine-induced thyrotoxicosis. J Appl Physiol 1985;58P:1485-8.

7 Harrison RN, Tattersfield AE. Airway response to inhaled salbutamol in hyperthyroid and hypothyroid patients before and after treatment. Thorax 1984;39:34-9.

8 Kendrick AH, O'Reilly JF, Laslo G. Lung function and exercise performance in hyperthyroidism before and after treatment. $Q J$ Med 1988;68:615-27.

9 Wasserman HP. Lung volume and respiratory muscle power in hyperthyroidism. S Afr Med J 1962;36:985-9. 